\title{
Functional Consequences of the Human Leptin Receptor (LEPR) Q223R Transversion
}

\author{
George Stratigopoulos ${ }^{1}$, Charles A. LeDuc ${ }^{1}$, Naoki Matsuoka ${ }^{2}$, Roee Gutman ${ }^{1}$, Richard Rausch ${ }^{1}$, \\ Scott A. Robertson ${ }^{3,4}$, Martin G. Myers Jr ${ }^{3,4}$, Wendy K. Chung ${ }^{1}$, Streamson C. Chua Jr ${ }^{5}$ and \\ Rudolph L. Leibel ${ }^{1}$
}

Perturbations in the functional integrity of the leptin axis are obvious candidates for mediation of altered adiposity. In a large number of genetic association studies in humans, the nonconservative LEPR Q223R allele has been inconsistently associated with adiposity. Subtle, long-term effects of such genetic variants can be obscured by effects of the environment and other confounders that render definitive inferences difficult to reach. We directly assessed the biological effects of this variant in 129P3/J mice segregating for the humanized Lepr allele at codon 223. No effects of this allele were detected on body weight, composition, or energy expenditure in animals fed diets of varying fat content over periods as long as 235 days. In vitro, Q223R did not affect leptin signaling as reflected by activation of STAT3. We conclude that Q223R is unlikely to play a significant role in regulation of human adiposity. This approach to vetting of human allelic variation might be more widely used.

Obesity (2008) 17, 126-135. doi:10.1038/oby.2008.489

\section{INTRODUCTION}

Leptin plays a central role in the control of human body weight as evidenced by the profound effects on adiposity of null alleles for leptin $(L E P)(1-4)$ or leptin receptor (LEPR) (5). A more difficult question is to what degree alleles of these genes-with more subtle effects on function or expression-contribute to human adiposity. This question is part of an even larger one: to what extent does allelic variation in genes in the known molecular pathways regulating body weight contribute in additive or epistatic ways to human adiposity?

In mice, haploinsufficiency for Lep or Lepr increases adiposity; and these effects are additive (6). In humans, comparable effects have been described for LEP (7). Genes in the signaling pathways engaged by leptin and other peripheral (insulin, ghrelin, peptide YY) and central (melanocortin 4 receptor, neuropeptide $\mathrm{Y}$, proopiomelanocortin, carboxypeptidase E) molecules have been examined by linkage and association studies for contributions to human adiposity. For example, the neuropeptide Y Leu7Pro polymorphism has been associated with higher BMI in premenopausal women (8) and young Dutch males (9). The ghrelin Leu72Met variant is associated with the age of onset of obesity (10). Positive associations with BMI have also been found with common variants of proopiomelanocortin and the melanocortin 4 receptor
(11-13). For LEP, associations of the G19A and Gln25Gln (CAA to CAG) polymorphisms with increased body weight have been reported $(14,15)$. Three missense variants Q223R, $\mathrm{K} 109 \mathrm{R}, \mathrm{K} 656 \mathrm{~N}$ in $L E P R$ with allele frequencies $>5 \%$ have been described, and their associations with adiposity examined $(16,17)$ (see below).

LEPR is a member of the class I cytokine receptor family with six alternative transcripts. In the mouse, the longest isoform (Leprb) is predominately expressed in hypothalamic and other CNS neurons that control food intake, energy balance, and neuroendocrine function, while the shorter isoforms are predominately expressed in several peripheral tissues where their physiological roles are not entirely clear (18-21). Leptin binding to mouse LEPRb (mLEPRb) stimulates the activity of the associated Janus kinase 2, which initiates intracellular signaling by phosphorylating three sites on the intracellular domain of mLEPRb leading to transcriptional regulation of neuropeptides and other molecules that exert effects on energy homeostasis (22-33). All six LEPR isoforms share the same extracellular domain consisting of two cytokine receptor homology $(\mathrm{CRH})$ domains, $\mathrm{CRH} 1$ and $\mathrm{CRH} 2$, separated by an immunoglobulin (Ig)-like domain and followed by three fibronectin type III (F3) domains (Figure 1). CRH2 is sufficient for leptin binding and activation of LEPR $(34,35)$. The CRH1

1'Division of Molecular Genetics, Department of Pediatrics, Naomi Berrie Diabetes Center, Columbia University, New York, New York, USA; ${ }^{2}$ Kobe City Medical Center General Hospital, Kobe, Japan; ${ }^{3}$ Division of Metabolism, Endocrinology and Diabetes, Department of Internal Medicine, University of Michigan, Ann Arbor, Michigan, USA; ${ }^{4}$ Department of Molecular and Integrative Physiology, University of Michigan, Ann Arbor, Michigan, USA; ${ }^{5}$ Diabetes Research and Training Center, Albert Einstein College of Medicine, Bronx, New York, USA. Correspondence: Rudolph L. Leibel (rl232@columbia.edu) 
a

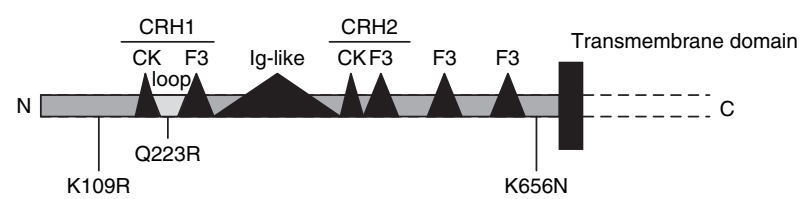

b
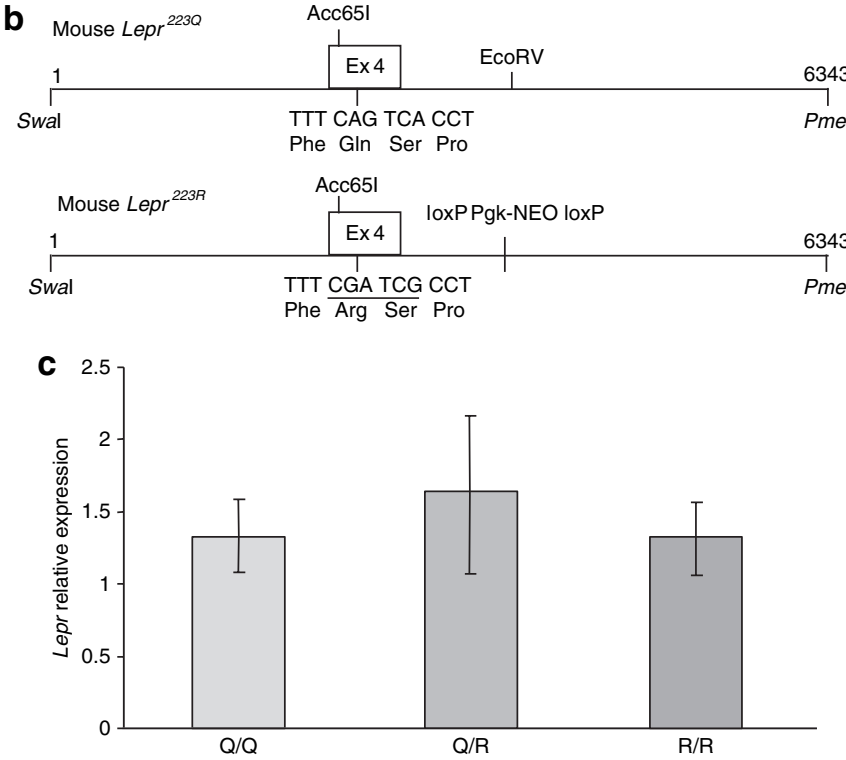

Figure 1 Extracellular domain of the leptin receptor. (a) Subdomains and locations of common polymorphisms of LEPR. (b) Generation of mice with the "humanized" leptin receptor. 223Q to 223R substitution (Q223R) in mouse exon 4. Restriction sites used for genotyping are indicated. (c) Expression levels in the hypothalamus of the three genotypes at amino acid 223 of Leprb. Expression data were normalized to $\beta$-actin $(N=3)$. CK, cytokine receptor subdomain; $\mathrm{CRH}$, cytokine receptor homology subdomain; F3, fibronectin type III subdomain; Ig, immunoglobulin.

domain is less conserved, and does not seem to participate in leptin binding or receptor activation (36).

The K109R polymorphism of LEPR causes a conservative change in the membrane-distal part of the LEPR extracellular domain (Figure 1). No apparent effect of K109R on BMI has been reported (16,37-42). K656N, a nonconservative change present in the membrane-proximal part of the LEPR extracellular domain, shows no association with adiposity (16,37-43). The Q223R nonconservative change is located in the CRH1 domain (Figure 1). A number of studies have reported associations of this variant with increased body weight and fat mass, whereas others failed to demonstrate the association (summarized in Table 1).

The aim of this study was to examine the functional consequences of Q223R by (i) assessing the effects of a humanized allele on body composition in the mouse; and (ii) measuring the functional activity of these Lepr alleles in cultured cells. Mice segregating for Lepr Q223R were generated, and gene dosage effects on adiposity and energy homeostasis were quantified. No effects of this allele were apparent either in vivo or in vitro; relevant caveats are discussed below. We propose that this approach will be useful in vetting the biological relevance of nonsynonymous variants in genes-mediating putative effects on quantitative traits such as adiposity.

\section{METHODS AND PROCEDURES}

\section{Humanized Lepr variant Q223R}

A targeting construct was designed to use homologous recombination in embryonic stem (ES) cells to replace coding exon 4 of the mouse Lepr gene with a segment that was identical except for codon 223. The targeting construct contained a $\sim 6 \mathrm{~kb}$ fragment (extending from a SwaI site to a PmeI site) that contains coding exon 4 . The codon substitution was accomplished by oligonucleotide-directed mutagenesis coupled with PCR. Two overlapping fragments were generated by PCR that encompassed coding exon 4 and flanking sequences. The codon sequence alteration was designed to introduce a novel $P v u I$ site and a novel TaqI site for diagnostic restriction digestions to identify the wild-type and novel alleles. The two overlapping fragments were digested with $P v u \mathrm{I}$, ligated, and reamplified to generate one contiguous fragment containing the codon sequence alteration. This fragment was digested with $A c c 65 \mathrm{I}$ and $E c o R V$ and used to replace a similar restriction fragment in the targeting construct. A floxed Pgk-neo cassette was inserted into the $E c o R V$ site that is downstream of coding exon 4 . All amplified segments were sequenced to eliminate clones with PCR-related sequence alterations (Figure 1b). The construct was used for targeting 129P3/J ES cells. Three G418 resistant clones were identified to have homologous recombination at the PGK-neo cassette by PCR. However, only two independent clones were verified to contain the desired codon alteration. Mice carrying the humanized Lepr 223R (equivalent to 222R in the mouse; for simplicity, it will be referred to as 223R) allele were generated by injecting the ES clone into C57BL/6J blastocysts. The floxed $P g k-n e o$ cassette was excised by mating to deleter protamine Cre 129 mice to prevent inadvertent effects due to interference from the Pgk-neo cassette. Mice carrying the neo-less allele were identified by PCR using primers flanking the Pgk-neo cassette insertion point.

The founder progeny (potentially capable of producing either 129 or B6 gametes) were crossed to 129 mice and the DNA of F1 progeny interrogated for the targeted Lepr allele. F1 animals segregating for the targeted Lepr allele (therefore 129 throughout) were intercrossed to generate the animals whose phenotypes are described below.

\section{Husbandry}

All mice were housed in groups of three to four per cage under a 12:12 hour light-dark cycle in a barrier facility at $21^{\circ} \mathrm{C}$. A total of $13223 \mathrm{R} / \mathrm{R}$, $35223 \mathrm{Q} / \mathrm{R}, 18223 \mathrm{Q} / \mathrm{Q}$ male and 23 223R/R, $28223 \mathrm{Q} / \mathrm{R}, 16223 \mathrm{Q} / \mathrm{Q}$ female mice were fed a low-fat (LF) diet (9\% of calories as fat; Purina Picolab no. 5058 chow; Granville Milling, Creedmoor, NC). In addition, 12 223R/R, $23223 \mathrm{Q} / \mathrm{R}, 16223 \mathrm{Q} / \mathrm{Q}$ male and 12 223R/R, $16223 \mathrm{Q} / \mathrm{R}$, 11 223Q/Q female mice were fed a LF (Purina Picolab no. 5058 chow; Granville Milling) or a high-fat (HF) (65\% of calories as fat; cat. no. D12492; Open Source Diets) diet starting at 4 weeks of age. Mice fed the LF diet from 4 weeks of age were switched to the HF diet at 121 days of age. All mice had ad libitum access to food and water throughout these studies.

\section{Body mass and composition measurement}

Mice were weighed weekly on an electronic scale starting on postnatal day 14. Immediately after weighing, body composition was determined by TD-NMR using a Minispec Analyst AD lean fat analyzer (Bruker Optics, Silberstreifen Germany). The TD-NMR was calibrated using mouse carcasses that ranged from 5 to $70 \mathrm{~g}$ in mass.

\section{Calorimetry and energy intake}

150-day-old male mice (four 223Q/Q and four 223R/R) were individually caged in a LabMaster-CaloSys-Calorimetry System (TSE Systems, Bad Homburg, Germany) and trained to use the water dispenser. Mice were weighed before being placed in their cages. Indirect calorimetry was performed for $\sim 96 \mathrm{~h}$ while the mice had free access to the LF diet. $\mathrm{O}_{2}$ and $\mathrm{CO}_{2}$ measurements were taken every $\sim 14$ min during the entire 


\section{GENETICS}

Table 1 Association studies of LEPR Q223R with human adiposity

\begin{tabular}{|c|c|c|c|c|c|c|c|}
\hline Authors & $\begin{array}{l}\text { Ethnicity/subject } \\
\text { type }\end{array}$ & Sample & Control & Association & $\begin{array}{c}\text { Allele } \\
\text { frequency }\end{array}$ & $\begin{array}{l}\text { Predisposing } \\
\text { allele }\end{array}$ & Dosage \\
\hline \multicolumn{8}{|l|}{ Positive association studies } \\
\hline Chagnon et al. (58) & $\begin{array}{l}\text { White } 99 \text { families: } \\
522 \text { subjects }\end{array}$ & & & $\begin{array}{l}4 \cup \text { increase } \\
\text { of BMl, } 5 \% \\
\text { increase in \%fat }\end{array}$ & $\mathrm{R}-0.43$ & $\mathrm{R}$ & Het/Hom \\
\hline Quinton et al. (59) & $\begin{array}{l}\text { White, } 220 \\
\text { postmenopausal } \\
\text { women }\end{array}$ & & & $\begin{array}{l}2 \cup \text { increase } \\
\text { of BMl, } 11 \% \\
\text { increase in fat } \\
\text { mass }\end{array}$ & R-0.6 & $\mathrm{R}$ & Het/Hom \\
\hline Guizar-Mendoza et al. (60) & $\begin{array}{l}\text { Mexican male } \\
\text { and female } \\
\text { adolescent }\end{array}$ & $\begin{array}{l}55 \text { obese } \\
(\mathrm{BMl}=31.1 \pm 3.6)\end{array}$ & $\begin{array}{l}48 \text { lean }(\mathrm{BMl}= \\
20.7 \pm 3.1)\end{array}$ & $\begin{array}{l}11 \% \text { increase in } \\
\% \text { fat }\end{array}$ & R-0.6 & $\mathrm{R}$ & Het/Hom \\
\hline Fairbrother et al. (61) & $\begin{array}{l}\text { White } \\
\text { postmenopausal } \\
\text { women }\end{array}$ & & & $\begin{array}{l}4 \% \text { increase in } \\
\text { fat mass }\end{array}$ & R-0.45 & $\mathrm{R}$ & Hom \\
\hline \multicolumn{8}{|l|}{ Negative association studies } \\
\hline Echwald et al. (39) & $\begin{array}{l}\text { Danish } \\
\text { adolescent males }\end{array}$ & 156 obese $(\mathrm{BMI} \geq 31)$ & $\begin{array}{l}205 \text { lean } \\
(\mathrm{BMI}= \\
21.5 \pm 2.2)\end{array}$ & None with BMI & & & \\
\hline Chagnon et al. (62) & $\begin{array}{l}\text { QFS/169 } \\
\text { families/314-325 } \\
\text { sib. pairs }\end{array}$ & 114 obese $(\mathrm{BMI} \geq 27)$ & $\begin{array}{l}167 \text { lean } \\
(\mathrm{BMl}<27)\end{array}$ & None with BMl & $\mathrm{R}-0.51$ & & \\
\hline de Silva et al. (63) & Nauruan males & 232 obese $(\mathrm{BMI}=37)$ & & None with BMl & R-0.89 & & \\
\hline Chagnon et al. (58) & $\begin{array}{l}\text { African-American } \\
115 \text { families: } 319 \\
\text { subjects }\end{array}$ & & & $\begin{array}{l}\text { None with BMI, } \\
\% \text { fat }\end{array}$ & R-0.51 & & \\
\hline Stefan et al. (64) & Pima Indians & $\begin{array}{l}268 \text { with low } \\
\text { subcut. fat }\end{array}$ & $\begin{array}{l}184 \text { with high } \\
\text { sub. fat }\end{array}$ & $\begin{array}{l}\text { None with abd., } \\
\text { sub. fat }\end{array}$ & R-0.33 & & \\
\hline Ogawa et al. (65) & $\begin{array}{l}\text { Japanese } \\
\text { middle-aged men } \\
\text { and women }\end{array}$ & $\begin{array}{l}175 \text { obese } \\
(\mathrm{BMI}=6.75 \pm 9.6)\end{array}$ & $\begin{array}{l}107 \text { lean } \\
(\mathrm{BMI}=21 \pm 1.4)\end{array}$ & None with BMl & R-0.85 & & \\
\hline van der Vleuten et al. (66) & $\begin{array}{l}\text { FCH patients, } \\
\text { diverse }\end{array}$ & $\begin{array}{l}158 \mathrm{FCH} \text { patients } \\
(\mathrm{BMI}=27.3)\end{array}$ & $\begin{array}{l}479 \text { relatives } \\
\text { and spouses } \\
\text { (BMl }=24.3 \\
26.4 \text { resp.) }\end{array}$ & $\begin{array}{l}\text { None with } \\
\text { BMI, waist } \\
\text { circumference }\end{array}$ & $\mathrm{R}-0.4$ & & \\
\hline Wang et al. (67) & $\begin{array}{l}\text { Taiwanese male } \\
\text { and female } \\
\text { Aborigines }\end{array}$ & $\begin{array}{l}226 \text { obese }(\mathrm{BMI} \geq 27) \\
33 \text { extreme }(\mathrm{BMI} \geq 35)\end{array}$ & $\begin{array}{l}182 \text { lean } \\
(\mathrm{BMl}<25)\end{array}$ & None with BMl & R-0.1 & & \\
\hline Mergen et al. (68) & $\begin{array}{l}\text { Turkish male and } \\
\text { female }\end{array}$ & 262 obese $(\mathrm{BMI} \geq 30)$ & $\begin{array}{l}138 \text { lean } \\
(\mathrm{BMl} \leq 25)\end{array}$ & None with BMl & R-0.38 & & \\
\hline
\end{tabular}



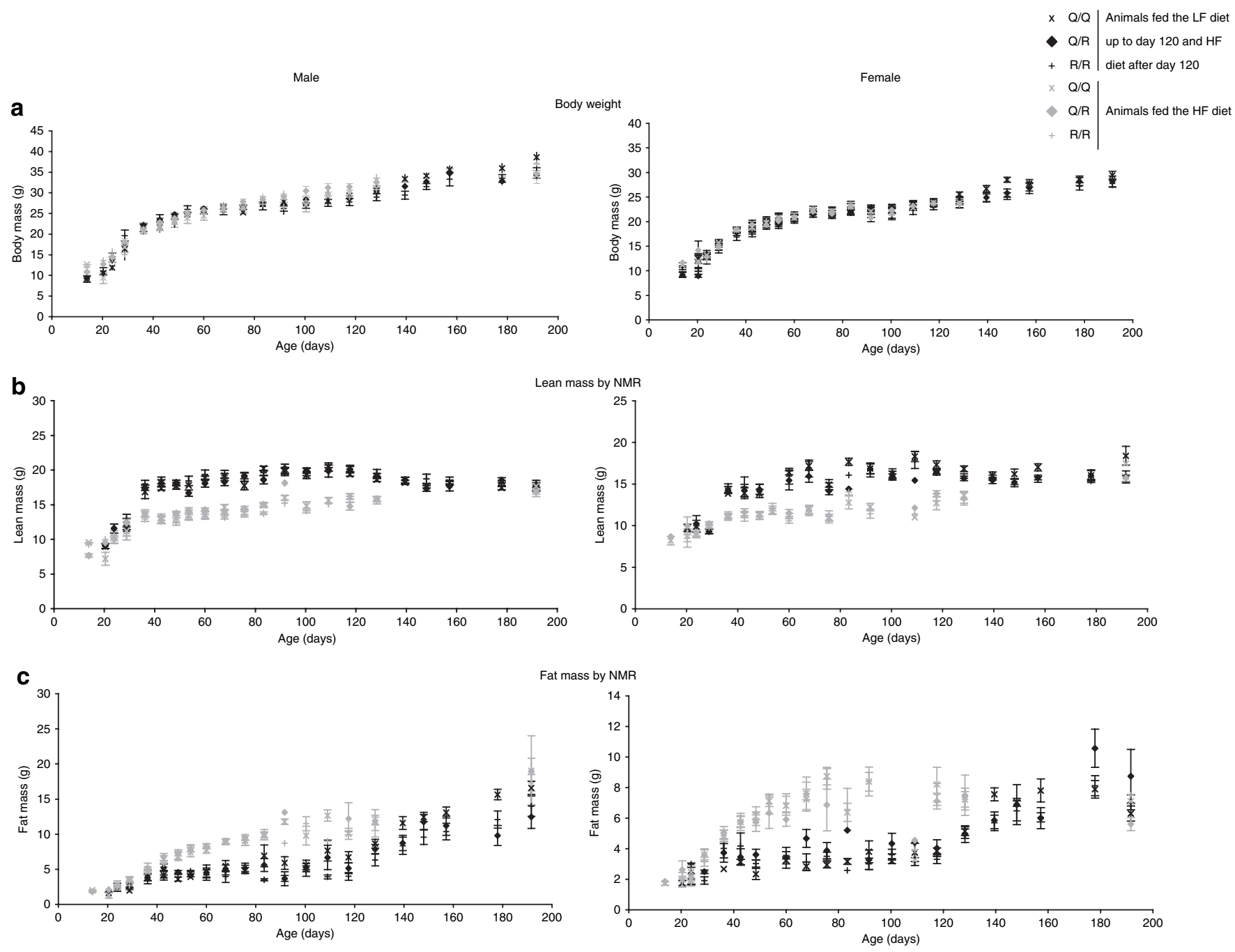

Figure 2 Body composition of mice fed the high-fat (HF) or low-fat (LF) diet by 223 genotype. Time course of (a) body weight, (b) lean mass, and (c) fat mass of male and female mice by genotype (at Lepr codon 223) fed the LF or HF diet. Body weight, lean and fat mass measurements of mice fed the HF diet were made every week from 14 to 130 days of age; an additional measurement was made at 190 days of age. For mice fed the LF diet, these measurements were made every week from 14 to 120 days of age. At day 121, their diet was switched to HF. Each data point is the arithmetic mean of all animals. Error bars represent s.e.m. For numbers of animals in each study, see Husbandry in Methods and Procedures section.

period, and $\mathrm{VO}_{2}$ and $\mathrm{VCO}_{2}$ values were expressed in $\mathrm{ml} / \mathrm{kg} / \mathrm{h}$. Mice were taken out of the calorimeter and fed the HF diet ad libitum for $72 \mathrm{~h}$. They were then returned to the calorimeter cages with $a d$ lib access to the HF diet and studied for $\sim 96 \mathrm{~h}$ as before. Data from only the last $72 \mathrm{~h}$ on the HF and LF diets were analyzed, as the mice were allowed to acclimate during the first $\sim 24 \mathrm{~h}$. Energy intake was calculated by multiplying cumulative food intake for a 24 -h period by the metabolizable energy present in the HF $(5.24 \mathrm{kcal} / \mathrm{g})$ and LF (3.56 kcal/g) diets.

\section{Real time PCR}

Total RNA was extracted from hypothalami of 15 mice of each of the three 223 genotypes and reverse transcribed using random hexamers (Invitrogen SuperScript III; Carlsbab, CA). Real-time PCR was performed in a LightCycler II (Roche, Pleasanton, CA) using the LightCycler FastStart DNA Master SYBR Green kit (Roche) according to the manufacturer's specifications. The following Lepr exonic primers were used: 5'-CCTCTGCCCCCACTGAAAGACA; 5'-GGGTCACTGTCACTCTGAAGTGCAA.

Lepr expression levels were normalized with $\beta$-actin using the following exonic primers: 5'-CTTTGCAGCTCCTTCGTTGC; 5'-TCTGACCCATTCCCACCATC.

\section{STAT3 activation assay}

Materials. Generation of anti-LEPRb antibody has been described previously (44). Antibody against $\mathrm{Tyr}_{705}$ phosphorylated STAT3 was purchased from Cell Signaling Technology (Boston, MA). Leptin was purchased from NHPP (Los Angeles, CA). mLEPRb/pCDNA3 has been described previously (45). The function of the $\Delta 65$ truncation in the intracellular domain of mLEPRb has been described and LEPRb $\triangle 65 /$ pCDNA3 is the nonchimeric variant which was used previously (46). mLEPRb/pCDNA3 was used as a template for mutagenesis. mLEPRb ${ }^{\mathrm{R} 223} / \mathrm{pCDNA} 3$ was constructed using a two-stage PCR method.

First, the $5^{\prime}$ flanking primer (5'-CGACTCACTATAGGGAGACCC AAGCTTG), and the antisense mutagenesis primer (5'-GACATCAGA GGTGACCGAAAACTCACACC), were used to amplify the upstream fragment.

The $3^{\prime}$ flanking primer (5'-GACATCGATCACGTATAATTCAGCAT AGCGGT), and the $5^{\prime}$ mutagenesis primer (5'-GGTGTGAGTTTTCGG TCACCTCTGATGTC) were used to amplify the downstream fragment. These PCR products combined and used as template for a second round of PCR using the flanking primers listed above. This PCR product was then inserted into mLEPRb/pCDNA3 using HindIII and XhoI restriction 
Table 2 Statistical analyses of body mass and composition measurements

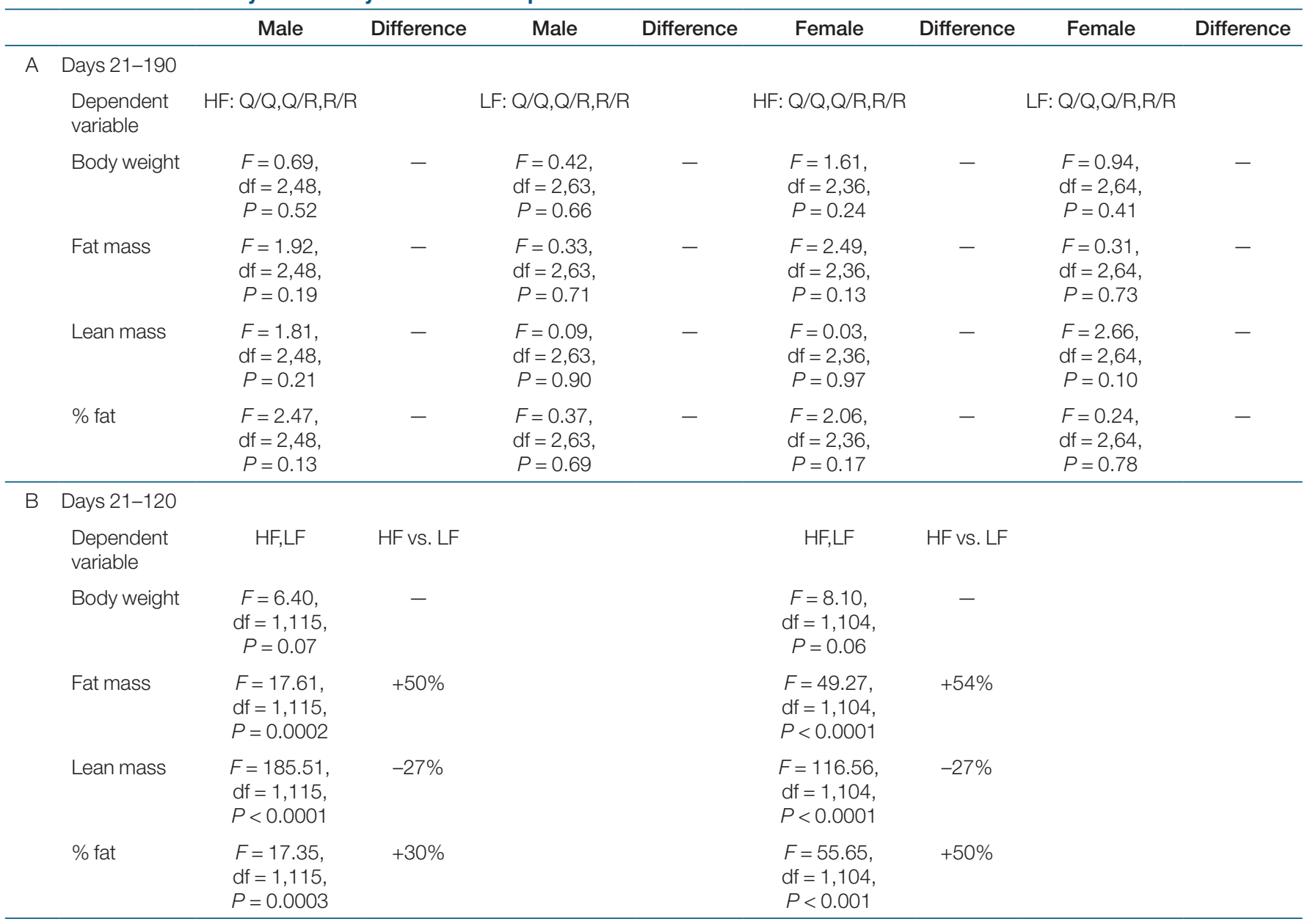

ANOVA for body mass and body composition by genotype at Lepr 223 in mice fed high-fat (HF) or low-fat (LF) diets up to day 190 . Area under the curve from data points taken every week was calculated for each mouse and grouped by (A) sex, diet, and genotype (up to day 190), or (B) sex and diet (up to day 120).

sites. The presence of the desired mutation and the absence of adventitious mutations was confirmed by DNA sequencing.

Cell lines and transfection. HEK 293 cells were maintained in a humidified incubator at $37^{\circ} \mathrm{C}$ with $5 \% \mathrm{CO}_{2}$. Dulbecco's modified Eagle medium supplemented with $10 \%$ fetal bovine serum, penicillin, and streptomycin was used as growth medium. The appropriate LEPRb and luciferase reporter plasmids were transiently transfected into 293 cells in 12-well plates using Lipofectamine (Invitrogen). $500 \mathrm{ng}$ LEPRb plasmid, 50 ng GAS-Luc (encodes STAT3-responsive $\gamma$ interferon-activated sequence driven luciferase), and $50 \mathrm{ng}$ pRL-TK (encodes Renilla luciferase) was transfected per well.

Immunoblotting. Following transfection, cells were switched to serumfree medium and stimulated for $6 \mathrm{~h}$ with various doses of leptin. Cells were harvested in lysis buffer $(20 \mathrm{mmol} / \mathrm{l}$ Tris $\mathrm{pH} 7.4,150 \mathrm{mmol} / \mathrm{l} \mathrm{NaCl}$, $1 \%$ Nonidet P-40) and insoluble material was cleared by centrifugation. Lysate was denatured in $4 \times$ Laemmli buffer and resolved by sodium dodecyl sulfate-polyacrylamide gel electrophoresis (SDS-PAGE). SDS-PAGE gels were transferred to nitrocellulose membranes in Towbin buffer containing $0.02 \%$ SDS and 20\% methanol. Membranes were blocked for $1 \mathrm{~h}$ in buffer containing $20 \mathrm{mmol} / \mathrm{l}$ Tris $(\mathrm{pH} \mathrm{7.4)}$, $150 \mathrm{mmol} / \mathrm{l} \mathrm{NaCl}$, and $0.01 \%$ Tween 20 (wash buffer) supplemented with 3\% bovine serum albumin (block buffer). Membranes were incubated with primary antibody for $2 \mathrm{~h}$ at room temperature. Membranes were washed three times and incubated with a horseradish peroxidase conjugated secondary antibody for $1 \mathrm{~h}$. Membranes were then washed three times, treated with luminescence reagent (Lumi-Light, Roche) and exposed to film.

Luciferase assays. Following transfection, cells were switched to serum-free medium and stimulated for $6 \mathrm{~h}$ with various doses of leptin. Cells were lysed and assayed with the Stop-n-Glo dual luciferase reporter kit (Promega, Madison, WI) according to the kit's instructions; GAS-Luc firefly luciferase activity was normalized for transfection efficiency with Renilla luciferase from the constitutive pRL-TK plasmid.

\section{Statistical analysis}

Changes in body composition over time of mice fed LF or HF diet up to days 120 or 190 were assessed using areas under the curves of body mass, lean mass, and fat mass over time for each mouse. One way ANOVA (StatView 5.0; SAS Institute) was used, grouping by sex, genotype, and diet. Effects of the LF and HF diet on energy intake and expenditure, $\mathrm{RQ}$ and $\mathrm{VO}_{2}$ were assessed by $t$-testing the arithmetic mean of the calorimetry readings over $72 \mathrm{~h}$. Levels of statistical significance were set at $P_{\alpha}<0.05$.

\section{Ethical use of animals}

We certify that all applicable institutional and governmental regulations concerning the ethical use of animals were followed during this research. All protocols were approved by the Columbia University Institutional Animal Care and Use Committee and were conducted in accordance with the National Institutes of Health Guide for the Care and Use of Laboratory Animals. 

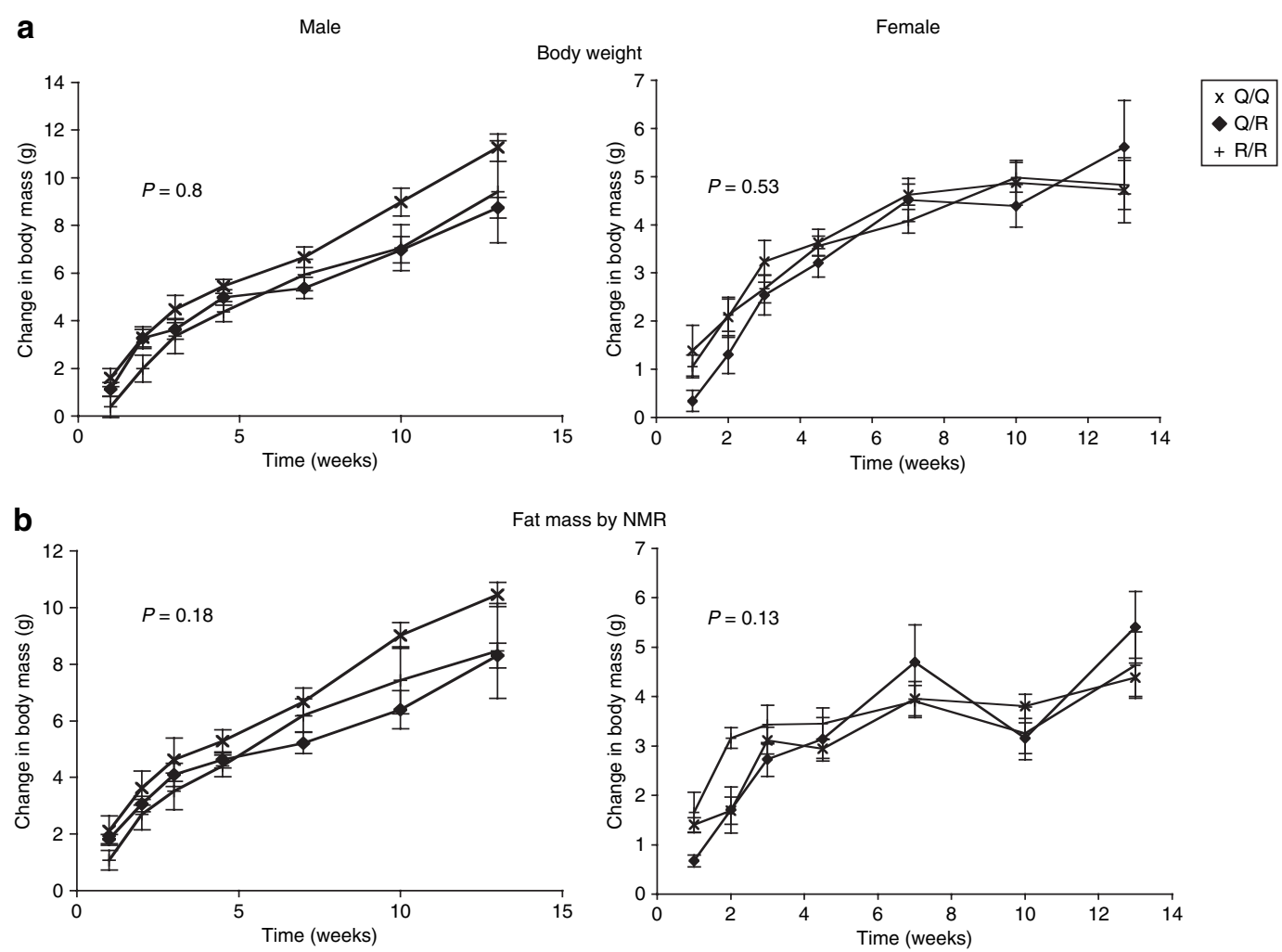

Figure 3 Body weight and composition by Lepr 223 genotype of mice switched to the high-fat (HF) diet at 121 days, Time course of (a) body weight, and (b) fat mass of male and female mice fed a HF diet for 13 weeks. Week 1 begins at day 121 of age, when mice were switched to the HF diet. Each data point represents a mean of all animals. Error bars represent s.e.m. Data analyzed by ANOVA. For numbers of animals in each study, see Husbandry in Methods and Procedures section.

\section{RESULTS}

\section{Body weight and composition}

Exon 4 of mouse Lepr is $76 \%$ identical at the DNA level and $70 \%$ identical at the amino acid level to the human LEPR. The substitution of the mouse wild-type glutamine residue $\left(\mathrm{Q}^{\mathrm{CAG}}\right)$ with arginine $\left(\mathrm{R}^{\mathrm{CGA}}\right)$ did not affect Lepr expression in the hypothalamus of mice heterozygous and homozygous for $\mathrm{R}^{\mathrm{CGA}}$ (Figure 1c). Genotype did not affect body mass in homozygous $(\mathrm{Q} / \mathrm{Q}, \mathrm{R} / \mathrm{R})$ and heretozygous $(\mathrm{Q} / \mathrm{R})$ male or female mice from 14 to 21 days of age (Figure $2 \mathrm{a}$ ). Mice of all three genotypes were then fed the HF or the LF diet until 120 days of age. From 14 to 120 days of age, there were effects of diet composition and sex-but not genotype-on changes in weight, lean and fat mass. (Figure 2; Table 2). Likewise, responses to the change to a HF diet at 120 days were unaffected by genotype at Lepr 223 (Figure 3; Table 2).

\section{Calorimetry}

Indirect calorimetry on $\mathrm{Q} / \mathrm{Q}$ and $\mathrm{R} / \mathrm{R}$ mice fed either the $\mathrm{LF}$ or HF diet showed, as expected, that mice on the LF diet had a higher RQ than mice on the HF diet; but this difference was unaffected by genotype at Lepr (Figure 4c). During these calorimetry studies, mice of neither genotype gained weight after 3 days on the HF or LF diet (Figure 4a), and had the same energy intake (Figure 4b) and energy expenditure (Figure 4e) per day while being fed the HF or LF diet. A time course of
$\mathrm{VO}_{2}$ per hour per body mass ${ }^{2 / 3}$ indicated that the 24-h energy expenditure and diurnal patterns of energy expenditure were indistinguishable between $\mathrm{Q} / \mathrm{Q}$ and $\mathrm{R} / \mathrm{R}$ mice fed the HF or LF diets (Figure 4d).

\section{In vitro signaling effects of codon 223 genotypes}

To investigate a possible alteration in signaling capacity between the 223Q and 223R Lepr alleles, we transfected plasmids encoding, STAT3-signaling defective Lepr $\Delta 65 \mathrm{C}$, native Leprb $^{223 \mathrm{Q}}$ or humanized Leprb ${ }^{223 \mathrm{R}}$ into 293 cells for the analysis of downstream signaling after treatment with various doses of leptin. The analysis of STAT3 activation by the detection of $\mathrm{Tyr}_{705}$ phosphorylation on endogenous STAT3 by immunoblotting revealed no differences in the extent of phosphorylation of STAT3 by Leprb ${ }^{223 \mathrm{Q}}$ or Leprb ${ }^{223 \mathrm{R}}$ (Figure 5b). Similarly, when Leprb ${ }^{223 \mathrm{Q}}$ or Leprb ${ }^{223 \mathrm{R}}$-mediated STAT3 transcriptional activation was assayed in 293 cells co-transfected with the STAT3-responsive GAS-luciferase reporter plasmid, no differences in leptin-dependent luciferase stimulation were detected between the two Leprb alleles over a range of leptin concentrations (Student's $t$-test, $P>0.05$ ) (Figure 5a).

\section{DISCUSSION}

The $\mathrm{Q}$ allele of LEPR is conserved in species from monotremes to humans (Ensemble; Genomic Sequence Alignment). The Q allele is also present in all mouse substrain sequences available at NCBI 
a

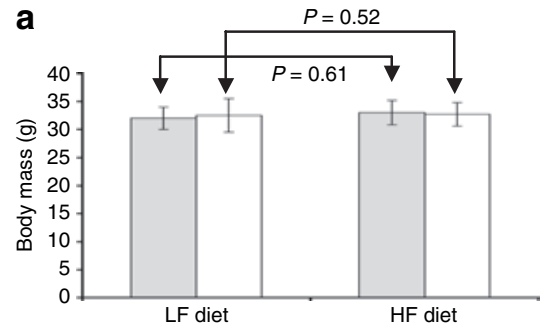

b

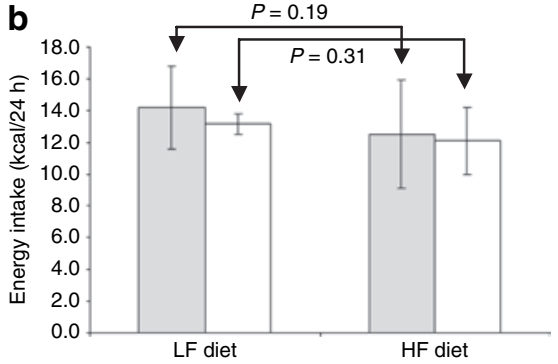

C

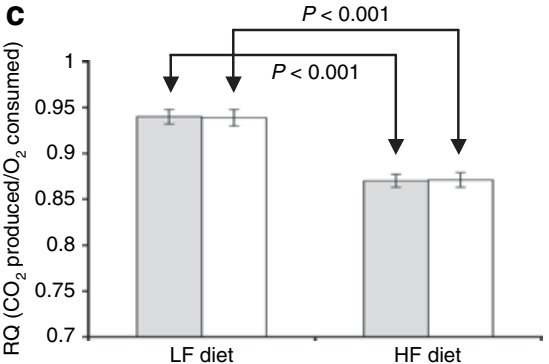

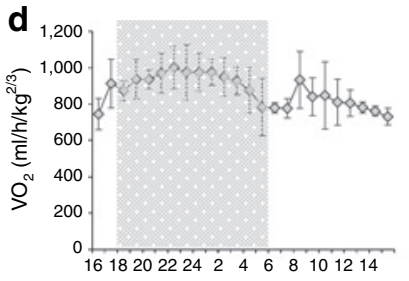

Time (h)
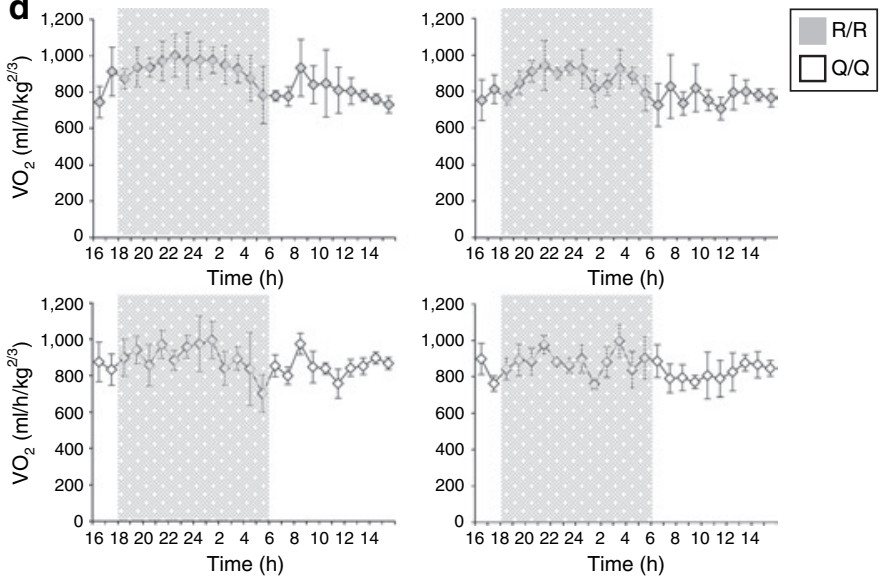

Time $(\mathrm{h})$
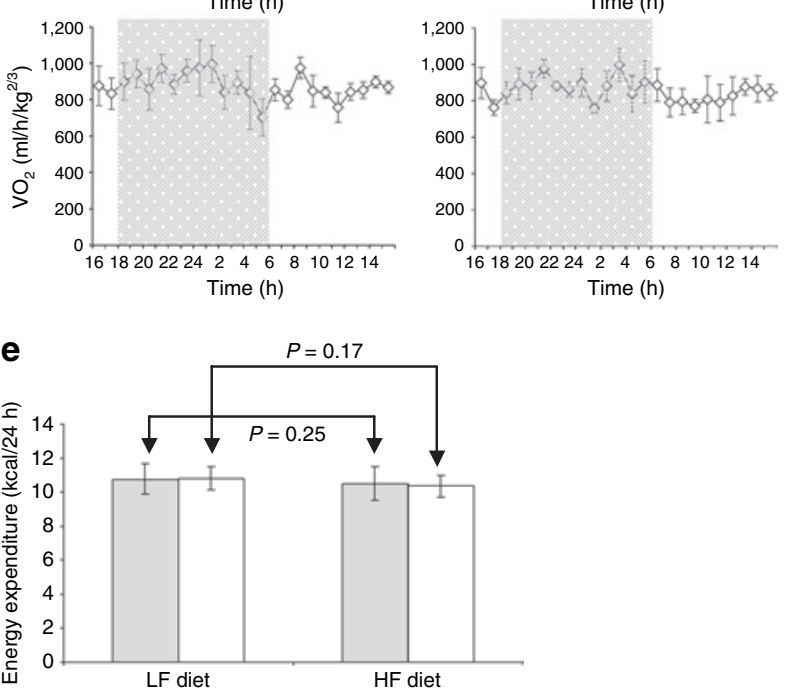

Figure 4 Metabolic studies of mice fed the high-fat (HF) or low-fat (LF) diet. Indirect calorimetry performed on mice homozygous for the 223Q or 223R Lepr alleles fed the LF or HF diets. Means and s.d. of (a) total body mass, (b) energy intake calculated from food intake, (c) respiratory quotient (RQ), (d) time course of oxygen utilization per hour over body mass raised to the $2 / 3$ power (dark background represents hours with lights out) and (e) energy expenditure. Measurements were taken every $\sim 14 \mathrm{~min}$ over a period of $72 \mathrm{~h}$. Columns and error bars represent means of respective readings and s.d., respectively. For numbers in each study, see Calorimetry in Results section.

(http://www.ncbi.nlm.nih.gov/SNP/MouseSNP.cgi). A number of studies have explored the hypothesis that the common, nonconservative variant, $L E P R$ Q223R, predisposes to increased adiposity in humans. Interest in $L E P R$ in this regard derives from its central role in energy homeostasis and the high frequency of this allele in most populations. The results, as noted, have been mixed, and two meta-analyses $(17,47)$ have concluded that $L E P R$ Q223R is not associated with relative adiposity or obesity. We used the mouse to attempt to make a more definitive finding regarding the biological significance of these alleles of $L E P R$.

$129 \mathrm{P} 3 / \mathrm{J}$ mice were transgenically engineered to segregate for the human alleles of LEPR at codon 223. Weight and body composition were assessed in male and female mice fed LF and HF diets over 235 days. Mice were also studied by indirect calorimetry. No effect of the Lepr Q223R genotype was observed for any of the metabolic or body weight/composition phenotypes. Possible reasons for our failure to detect any functional consequence of amino acid substitution at this locus include: (i) use of Lepr DNA sequence from a mouse strain with unique characteristics rendering the molecule insensitive to the allelic variant; (ii) a corollary possibility related to interactions between the mouse Lepr sequence and the "background" genome of the mice examined in this study; (iii) the presence
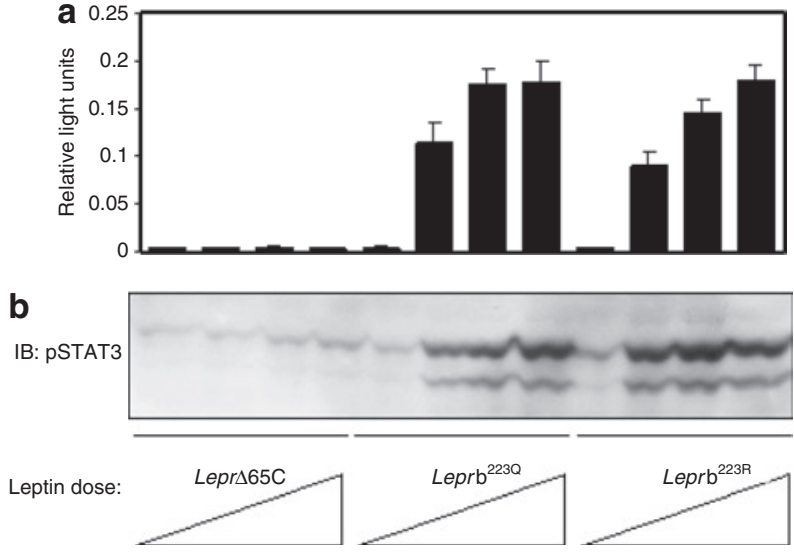

Figure 5 In vitro assessment of leptin receptor activity. Activation of STAT3 in response to leptin stimulation. HEK 293 cells were transfected with the Lepr $65 \mathrm{C}$ (truncated Lepr), Leprb ${ }^{\mathrm{Q} 223}$ (native mouse Lepr) and Leprb'R223 ("humanized" Lepr) plasmids, as well as the STAT3responsive GAS-luciferase and control pRL-TK plasmids. Following transfection, cells were made quiescent, then treated with leptin for $6 \mathrm{~h}$ before lysis. Leptin doses were $0,20 \mathrm{ng} / \mathrm{ml}, 200 \mathrm{ng} / \mathrm{ml}$, and $2 \mathrm{mg} /$ $\mathrm{ml}$. Lysates were either subjected to (a) dual luciferase analysis or (b) resolved by SDS-PAGE before transferring to nitrocellulose and immunoblot with the indicated antibody. Bars represent the means of triplicate determinations plus or minus the s.d. 


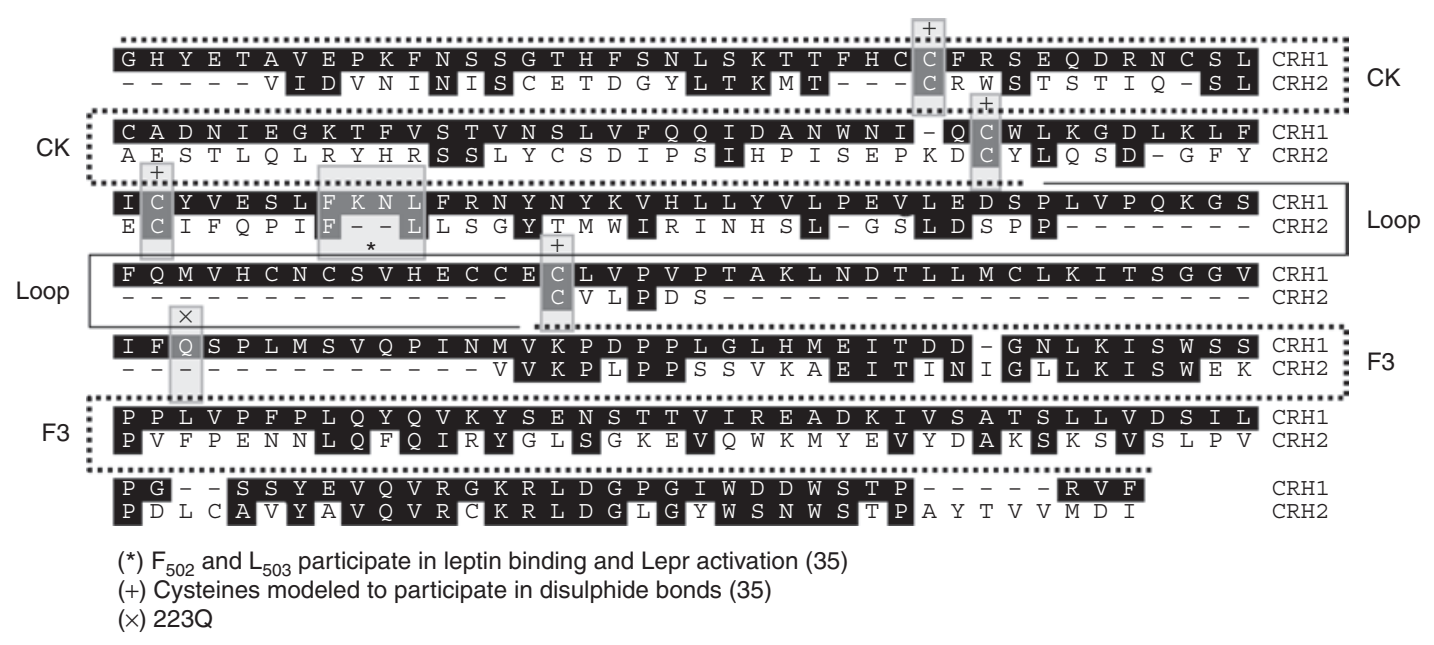

Figure 6 Comparison of $\mathrm{CRH} 1$ and $\mathrm{CRH} 2$. Alignment of human $\mathrm{CRH} 1$ and $\mathrm{CRH} 2$ using the Clustal $\mathrm{V}$ method. Although the two subdomains show weak identity, key residues are conserved.

of critical differences between mouse and human amino acid sequences in LEPR limiting the impact of the Q223R on a relevant signaling pathway. With regard to (i), there are no coding or intronic splice site sequence differences in Lepr among mouse strains examined to date (NCBI; http://www.ncbi.nlm. nih.gov/SNP/MouseSNP.cgi; database includes sequence from 125 mouse strains). Point (ii) is addressed in the penultimate paragraph of the article, just below. With regard to (iii), the mouse LEPRb is $\sim 75 \%$ identical at the amino acid level to the human protein (mLEPRb NCBI accession no. CAA71342; Human LEPRb NCBI accession no. NP_002294). In particular, mLEPRb residues associated with Janus kinase 2 (human residues 893-898) (ref. 48), STAT3 (human residues 1,1421,145) (ref. 49), SOCS3 (human residue 1,142; 27), STAT5 (human residues 1,079-1,082) (refs. 23,50), SHP-2 (human residues 987-990 including Tyr 987 involved in the generation of mLEPRb autoinhibitory signals) $(27,51)$ activities are conserved between mouse and human proteins. Similarly, the extracellular domain responsible for leptin binding (mouse residues $323-640$ ) is $85 \%$ identical between mouse and human LEPR (34). Specifically, residues within sites I-III modeled to bind leptin are conserved in both mouse and human $(36,52)$.

The LEPR Q223R substitution is located in the loop connecting the cytokine receptor (CK) and the fibronectin type III (F3) domains of CRH1 (Figure 1a). Residues in the Ig-like (36), CRH2 (ref. 35), and membrane-proximal F3 (ref. 53) domains have been implicated in LEPR function. No role has yet been assigned to CRH1 because it is not necessary for leptin binding or LEPR activity (36). CRH1 and CRH2 are $23 \%$ identical at the amino acid level. Despite the conservation of critical CRH2 residues in CRH1, the Q223R polymorphism lies in a region unique to CRH1 (Figure 6), that is not conserved in a number of related cytokine receptors (34). In contrast, the mutation that underlies the leptin insensitivity of fatty rats (Q269P) lies within an important structural subdomain of CRH1, and the Q269P substitution presumably destabilizes the structure of CRH1 and thus the entire LEPR molecule $(34,54,55)$. Whatever the functional role (if any) of the LEPR Q223R polymorphism may be, it does not appear to affect leptin signaling as reflected by in vitro activation of STAT3, or the body composition/metabolic performance of mice studied over relatively long periods of time. We conclude from the present analysis that LEPR Q223R is unlikely to play a significant role in risk of human obesity.

The previous association detected in the human association studies may be due to another polymorphism in linkage disequilibrium with LEPR Q223R, or could simply be a spurious finding. There is an important caveat to our conclusions regarding the likely absence of functional consequences of the Q223R alleles of LEPR. We examined the effects of these alleles in a single mouse strain (129P3/J). It is well known that the phenotypic "penetrance" of spontaneous and engineered mutations varies widely depending upon the strain(s) in which the mutation is segregated. The striking differences in diabetesrelated phenotypes of Lepr ${ }^{d b}$ mutations on the C57BLKS/J and C57BL/6J backgrounds (56) is a relevant example. This sort of effect may also account for apparent racial differences in the phenotypic consequences of genetic variation in humans (e.g., TCF7L2) (ref. 57). Clearly, studies of the sort described here must be interpreted in the context of such considerations. In this instance, given the discordant results in human studies, our in vivo results in 129 mice, and our in vitro analysis of signaling by the Q223R alleles, we conclude that Q223R allelic variation in $L E P R$ plays a small role (if any) in human adiposity.

The approach used here was designed to provide a prototype for biological assessment of potentially small effects of allelic variants in candidate genes for complex convergent phenotypes such as human obesity. This approach can be used to examine alleles of several genes at one time, to recapitulate implicated haplotypes without confounding due to other genetic variation, or variable environments.

\section{ACKNOWLEDGMENTS}

This work was supported by RO1 DK52431, R01 DK57631, and an ADA mentored fellowship award. Work was also supported by the New York 
Obesity Research Center (Grant no. 5P30 DK26687-27) and predoctoral training awards from the ADA and AHA.

\section{DISCLOSURE}

The authors declared no conflict of interest.

(C) 2008 The Obesity Society

\section{REFERENCES}

1. Montague CT, Faroogi IS, Whitehead JP et al. Congenital leptin deficiency is associated with severe early-onset obesity in humans. Nature 1997;387:903-908

2. Faroogi IS, Matarese G, Lord GM et al. Beneficial effects of leptin on obesity, T cell hyporesponsiveness, and neuroendocrine/metabolic dysfunction of human congenital leptin deficiency. J Clin Invest 2002;110:1093-1103.

3. Gibson WT, Faroogi IS, Moreau M et al. Congenital leptin deficiency due to homozygosity for the Delta133G mutation: report of another case and evaluation of response to four years of leptin therapy. J Clin Endocrinol Metab 2004:89:4821-4826.

4. Strobel A, Issad T, Camoin L, Ozata M, Strosberg AD. A leptin missense mutation associated with hypogonadism and morbid obesity. Nat Genet 1998;18:213-215.

5. Clément $\mathrm{K}$, Vaisse $\mathrm{C}$, Lahlou $\mathrm{N}$ et al. A mutation in the human leptin receptor gene causes obesity and pituitary dysfunction. Nature 1998;392:398-401.

6. Chung WK, Belfi K, Chua M et al. Heterozygosity for Lep(ob) or Lepr(db) affects body composition and leptin homeostasis in adult mice. Am J Physiol 1998:274: R985-R990.

7. Faroogi IS, Keogh JM, Kamath S et al. Partial leptin deficiency and human adiposity. Nature 2001;414:34-35.

8. Mattevi VS, Zembrzuski VM, Hutz MH. Association analysis of genes involved in the leptin-signaling pathway with obesity in Brazil. Int $J$ Obes Relat Metab Disord 2002;26:1179-1185.

9. van Rossum CT, Pijl H, Adan RA, Hoebee B, Seidell JC. Polymorphisms in the NPY and AGRP genes and body fatness in Dutch adults. Int $J$ Obes (Lond) 2006;30:1522-1528.

10. Miraglia del Giudice E, Santoro N, Cirillo G et al. Molecular screening of the ghrelin gene in Italian obese children: the Leu72Met variant is associated with an earlier onset of obesity. Int J Obes Relat Metab Disord 2004;28:447-450

11. Young EH, Wareham NJ, Faroogi S et al. The V103l polymorphism of the MC4R gene and obesity: population based studies and meta-analysis of 29 563 individuals. Int J Obes (Lond) 2007:31:1437-1441.

12. Chen $\mathrm{Y}$, Snieder $\mathrm{H}$, Wang $\mathrm{X}$ et al. Proopiomelanocortin gene variants are associated with serum leptin and body fat in a normal female population. Eur J Hum Genet 2005;13:772-780.

13. Baker M, Gaukrodger N, Mayosi BM et al. Association between common polymorphisms of the proopiomelanocortin gene and body fat distribution: a family study. Diabetes 2005;54:2492-2496.

14. Hager J, Clement $\mathrm{K}$, Francke $\mathrm{S}$ et al. A polymorphism in the $5^{\prime}$ untranslated region of the human ob gene is associated with low leptin levels. Int $J$ Obes Relat Metab Disord 1998:22:200-205

15. Ohshiro Y, Ueda K, Nishi M et al. A polymorphic marker in the leptin gene associated with Japanese morbid obesity. J Mol Med 2000:78:516-520.

16. Chung WK, Power-Kehoe L, Chua M et al. Exonic and intronic sequence variation in the human leptin receptor gene (LEPR). Diabetes 1997;46: 1509-1511.

17. Paracchini V, Pedotti P, Taioli E. Genetics of leptin and obesity: a HuGE review. Am J Epidemiol 2005:162:101-114.

18. Bjørbæk C, Kahn BB. Leptin signaling in the central nervous system and the periphery. Recent Prog Horm Res 2004;59:305-331.

19. de Luca C, Kowalski TJ, Zhang Y et al. Complete rescue of obesity, diabetes, and infertility in $\mathrm{db} / \mathrm{db}$ mice by neuron-specific LEPR-B transgenes. J Clin Invest 2005;115:3484-3493.

20. Kowalski TJ, Liu SM, Leibel RL, Chua SC Jr. Transgenic complementation of leptin-receptor deficiency. I. Rescue of the obesity/diabetes phenotype of LEPR-null mice expressing a LEPR-B transgene. Diabetes 2001;50:425-435.

21. Chua SC Jr, Liu SM, Li Q et al. Transgenic complementation of leptin receptor deficiency. II. Increased leptin receptor transgene dose effects on obesity/diabetes and fertility/lactation in lepr-db/db mice. Am J Physiol Endocrinol Metab 2004;286: E384-E392.

22. Bates SH, Stearns WH, Schubert M et al. STAT3 signaling is required for leptin regulation of energy balance but not reproduction. Nature 2003:421:856-859.
23. Gong Y, Ishida-Takahashi R, Villanueva EC et al. The long form of the leptin receptor regulates STAT5 and ribosomal protein S6 via alternate mechanisms. J Biol Chem 2007;282:31019-31027.

24. Baumann H, Morella KK, White DW et al. The full-length leptin receptor has signaling capabilities of interleukin 6-type cytokine receptors. Proc Natl Acad Sci USA 1996;93:8374-8378.

25. Banks AS, Davis SM, Bates SH, Myers MG Jr. Activation of downstream signals by the long form of the leptin receptor. J Biol Chem 2000;275:14563-14572.

26. Bjørbaek C, Buchholz RM, Davis SM et al. Divergent roles of SHP-2 in ERK activation by leptin receptors. J Biol Chem 2001;276:4747-4755.

27. Bjørbaek C, Lavery HJ, Bates SH et al. SOCS3 mediates feedback inhibition of the leptin receptor via Tyr985. J Biol Chem 2000;275:40649-40657.

28. Björnholm M, Münzberg H, Leshan RL et al. Mice lacking inhibitory leptin receptor signals are lean with normal endocrine function. J Clin Invest 2007;117:1354-1360.

29. Minokoshi Y, Alquier T, Furukawa N et al. AMP-kinase regulates food intake by responding to hormonal and nutrient signals in the hypothalamus. Nature 2004:428:569-574.

30. Niswender KD, Morton GJ, Stearns WH et al. Intracellular signalling. Key enzyme in leptin-induced anorexia. Nature 2001;413:794-795.

31. Cota D, Proulx K, Smith KA et al. Hypothalamic mTOR signaling regulates food intake. Science 2006:312:927-930.

32. Xu AW, Kaelin CB, Takeda K et al. PI3K integrates the action of insulin and leptin on hypothalamic neurons. J Clin Invest 2005;115:951-958.

33. Plum L, Ma X, Hampel B et al. Enhanced PIP3 signaling in POMC neurons causes KATP channel activation and leads to diet-sensitive obesity. J Clin Invest 2006;116:1886-1901.

34. Fong TM, Huang RR, Tota MR et al. Localization of leptin binding domain in the leptin receptor. Mol Pharmacol 1998;53:234-240.

35. Iserentant $\mathrm{H}$, Peelman F, Defeau D et al. Mapping of the interface between leptin and the leptin receptor CRH2 domain. J Cell Sci 2005;118:2519-2527.

36. Peelman F, Iserentant $\mathrm{H}$, De Smet AS et al. Mapping of binding site III in the leptin receptor and modeling of a hexameric leptin.leptin receptor complex. J Biol Chem 2006:281:15496-15504.

37. Silver K, Walston J, Chung WK et al. The Gln223Arg and Lys656Asn polymorphisms in the human leptin receptor do not associate with traits related to obesity. Diabetes 1997;46:1898-1900.

38. Mammès $\mathrm{O}$, Aubert $\mathrm{R}$, Betoulle $\mathrm{D}$ et al. LEPR gene polymorphisms: associations with overweight, fat mass and response to diet in women. Eur $J$ Clin Invest 2001;31:398-404.

39. Echwald SM, Sørensen TD, Sørensen TI et al. Amino acid variants in the human leptin receptor: lack of association to juvenile onset obesity. Biochem Biophys Res Commun 1997;233:248-252.

40. Yiannakouris N, Yannakoulia M, Melistas L et al. The Q223R polymorphism of the leptin receptor gene is significantly associated with obesity and predicts a small percentage of body weight and body composition variability. J Clin Endocrinol Metab 2001:86:4434-4439.

41. Matsuoka N, Ogawa Y, Hosoda K et al. Human leptin receptor gene in obese Japanese subjects: evidence against either obesity-causing mutations or association of sequence variants with obesity. Diabetologia 1997:40:1204-1210.

42. Thompson DB, Ravussin E, Bennett PH, Bogardus C. Structure and sequence variation at the human leptin receptor gene in lean and obese Pima Indians. Hum Mol Genet 1997;6:675-679.

43. Gotoda T, Manning BS, Goldstone AP et al. Leptin receptor gene variation and obesity: lack of association in a white British male population. Hum Mol Genet 1997:6:869-876.

44. Banks AS, Davis SM, Bates SH, Myers MG Jr. Activation of downstream signals by the long form of the leptin receptor. J Biol Chem 2000;275:14563-14572.

45. Bjørbæk C, Uotani S, da Silva B, Flier JS. Divergent signaling capacities of the long and short isoforms of the leptin receptor. J Biol Chem 1997:272:32686-32695.

46. Kloek C, Haq AK, Dunn SL et al. Regulation of Jak kinases by intracellular leptin receptor sequences. J Biol Chem 2002;277:41547-41555.

47. Heo M, Leibel RL, Fontaine KR et al. A meta-analytic investigation of linkage and association of common leptin receptor (LEPR) polymorphisms with body mass index and waist circumference. Int J Obes Relat Metab Disord 2002;26:640-646.

48. Bahrenberg G, Behrmann I, Barthel A et al. Identification of the critical sequence elements in the cytoplasmic domain of leptin receptor 
isoforms required for Janus kinase/signal transducer and activator of transcription activation by receptor heterodimers. Mol Endocrinol 2002;16:859-872.

49. Haan S, Hemmann U, Hassiepen U et al. Characterization and binding specificity of the monomeric STAT3-SH2 domain. J Biol Chem 1999;274:1342-1348.

50. Hekerman P, Zeidler J, Bamberg-Lemper S et al. Pleiotropy of leptin receptor signalling is defined by distinct roles of the intracellular tyrosines. FEBS J 2005;272:109-119.

51. Björnholm M, Münzberg H, Leshan RL et al. Mice lacking inhibitory leptin receptor signals are lean with normal endocrine function. J Clin Invest 2007; 117:1354-1360.

52. Peelman F, Van Beneden K, Zabeau L et al. Mapping of the leptin binding sites and design of a leptin antagonist. J Biol Chem 2004;279: 41038-41046.

53. Zabeau L, Defeau D, Iserentant $\mathrm{H}$ et al. Leptin receptor activation depends on critical cysteine residues in its fibronectin type III subdomains. J Biol Chem 2005;280:22632-22640.

54. Chua SC Jr, Chung WK, Wu-Peng XS et al. Phenotypes of mouse diabetes and rat fatty due to mutations in the OB (leptin) receptor. Science 1996;271:994-996.

55. White DW, Wang DW, Chua SC Jr et al. Constitutive and impaired signaling of leptin receptors containing the Gln --> Pro extracellular domain fatty mutation. Proc Natl Acad Sci USA 1997;94:10657-10662.

56. Coleman DL. The influence of genetic background on the expression of mutations at the diabetes (db) locus in the mouse. Vl: Hepatic malic enzyme activity is associated with diabetes severity. Metabolism 1992;41: 1134-1136.

57. Guo T, Hanson RL, Traurig M et al. TCF7L2 is not a major susceptibility gene for type 2 diabetes in Pima Indians: analysis of 3,501 individuals. Diabetes 2007:56:3082-3088.

58. Chagnon YC, Wilmore JH, Borecki IB et al. Associations between the leptin receptor gene and adiposity in middle-aged Caucasian males from the HERITAGE family study. J Clin Endocrinol Metab 2000;85: 29-34.
59. Quinton ND, Lee AJ, Ross RJ, Eastell R, Blakemore Al. A single nucleotide polymorphism (SNP) in the leptin receptor is associated with BMI, fat mass and leptin levels in postmenopausal Caucasian women. Hum Genet 2001;108:233-236.

60. Guizar-Mendoza JM, Amador-Licona N, Flores-Martinez SE et al. Association analysis of the Gln223Arg polymorphism in the human leptin receptor gene, and traits related to obesity in Mexican adolescents. J Hum Hypertens 2005;19:341-346.

61. Fairbrother UL, Tanko LB, Walley AJ et al. Leptin receptor genotype at Gln223Arg is associated with body composition, BMD, and vertebral fracture in postmenopausal Danish women. J Bone Miner Res 2007;22:544-550.

62. Chagnon YC, Chung WK, Perusse L et al. Linkages and associations between the leptin receptor (LEPR) gene and human body composition in the Quebec Family Study. Int J Obes Relat Metab Disord 1999;23:278-286.

63. de Silva AM, Walder KR, Aitman TJ et al. Combination of polymorphisms in $\mathrm{OB}-\mathrm{R}$ and the $\mathrm{OB}$ gene associated with insulin resistance in Nauruan males. Int J Obes Relat Metab Disord 1999;23:816-822.

64. Stefan N, Vozarova B, Del Parigi A et al. The Gln223Arg polymorphism of the leptin receptor in Pima Indians: influence on energy expenditure, physical activity and lipid metabolism. Int J Obes Relat Metab Disord 2002;26: 1629-1632.

65. Ogawa T, Hirose H, Yamamoto $Y$ et al. Relationships between serum soluble leptin receptor level and serum leptin and adiponectin levels, insulin resistance index, lipid profile, and leptin receptor gene polymorphisms in the Japanese population. Metabolism 2004;53:879-885.

66. van der Vleuten GM, Kluijtmans LA, Hijmans A et al. The Gln223Arg polymorphism in the leptin receptor is associated with familial combined hyperlipidemia. Int J Obes (Lond) 2006;30:892-898.

67. Wang TN, Huang MC, Chang WT et al. G-2548A polymorphism of the leptin gene is correlated with extreme obesity in Taiwanese aborigines. Obesity (Silver Spring) 2006;14:183-187.

68. Mergen H, Karaaslan C, Mergen M, Deniz Ozsoy E, Ozata M. LEPR, ADBR3, IRS-1 and 5-HTT genes polymorphisms do not associate with obesity. Endocr J 2007;54:89-94. 